\title{
Performance Evaluation of Uncoated Carbide Tool in High Speed Drilling of Ti6Al4V*
}

\author{
Erween Abd. RAHIM ${ }^{* *}$, Kamaruddin KAMDANI $^{* *}$ and Safian SHARIF ${ }^{* * *}$ \\ ** Faculty of Mechanical and Manufacturing Engineering, \\ Universiti Tun Hussein Onn Malaysia, 86400 Johor, Malaysia . \\ E-mail:kmarudin@uthm.edu.my \\ *** Faculty of Mechanical Engineering, \\ Universiti Teknologi Malaysia, 81310 Johor, Malaysia
}

\begin{abstract}
This paper presents the experimental investigation into the performance of the uncoated carbide tool when high speed drilling (HSD) of Ti6Al4V. Machining responses such as thrust force, torque, vibration, chip formation and surface integrity of drilled surface were evaluated at various cutting conditions. Results show that cutting speed and feed significantly influenced the above responses. Folded wavy type chips and curly type chips were produced under all tested cutting conditions. It was also found that the transition from aperiodic to periodic chip formation occurred as the cutting speed increases. In addition, improvement of the drilling performance was also recorded as a result of reduction of acceleration amplitude during peck drilling method was adopted. Observation on the subsurface of the drilled workpiece indicates a severe plastic deformation at all tested cutting conditions.
\end{abstract}

Key words: High Speed Drilling, Titanium Alloy, Ti6Al4V

\section{Introduction}

Today high speed machining (HSM) can be considered as state of the art technology and it commonly refers to end milling at high spindle speeds and high surface feeds. Over the past 60 years, high speed machining technology has already been applied to many manufacturing industries such as the aviation and aerospace industry, automobile industry, mould industry to cut a wide range of metallic and non-metallic workpiece materials [1]. The applications of HSM on various materials seems to rapidly advanced over the years to come due to the superior advantages such as increased productivity, generating good surface finish, capability to machine complex parts, reducing the cutting forces and reduced the heat generated during machining [2-4].

Ti6Al4V is the most popular among the titanium alloy grades with its widespread use in aerospace industry, surgical, chemical and ship building. Numerous research efforts have been conducted on milling and turning of Ti6Al4V at high cutting speeds [4-10]. Sakurai et al. [11] presented a work which discusses the machinability of Ti6Al4V that was subjected to various cutting strategies which includes intermittent deceleration feed drilling, vibratory drilling and the use of high pressure of coolant at spindle speed of $570 \mathrm{rpm}$. Promising results were exhibited which include formation of easy-to-eliminate chips, reduced chip clogging and increased chip removal. On the other hand, the intermittent deceleration feed drilling has the lowest wear hence improved the tool life. 
Arai and Ogawa [12] studied the drilling performance of Ti6Al4V under high pressure coolant at spindle speed ranging from 150 to $1100 \mathrm{rpm}$. They had confirmed that the application of high pressure coolant could prolong the tool life in drilling of Ti6Al4V. Sharif et al. [13] analyzed the effects of coatings (TiAlN and Supernitride) on the tool life of carbide tool when drilling Ti6Al4V. They found that the higher percentage of aluminium content in Supernitride coating recorded the lowest tool wear rate. In another work, Cantero et al. [14] have conducted a test to drill a Ti6Al4V under dry cutting condition at cutting speed ranging between 25 to $65 \mathrm{~m} / \mathrm{min}$. They suggested to use a moderate cutting parameter in order to achieved optimum tool life.

Recently, Zeilmann and Weingaerner [15] analyzed the temperature generated during drilling of the titanium alloy Ti6Al4V at cutting speed ranging from 15 to $50 \mathrm{~m} / \mathrm{min}$ under minimal quantity of lubricant (MQL). By applying the MQL through the tool, the cutting temperature decreased $50 \%$ when compared with MQL applied with an external nozzle. Rahim and Sharif [16] have investigated the machinability of drilling Ti6Al4V and Ti5 Al4VMo/Fe in the speed range of 25 to $45 \mathrm{~m} / \mathrm{min}$. They found that Ti6Al4V exhibited a more superior machinability characteristics when compared to the Ti5A14VMo/Fe. Excessive plastic deformation on the subsurface layer was observed and this is probably the reason of increase in the hardness value.

High speed drilling (HSD) posed a challenging characteristic since most of the current commercial drill geometry could not be used to satisfy tool life. All the works mentioned in the previous paragraph used low to moderate cutting speed. Researchs on HSD of titanium and its alloys are limited and not widely reported. In this regard, Okamura et al. [17] have discussed the effect of low-frequency vibration in drilling of titanium alloy at 10,000 rpm spindle speed. They found that low-frequency vibration drilling can control chip formation, reduced drilling temperature and increased the tool life performance. Recently, $\mathrm{Li}$ et al. [18] investigated the high-throughput drilling of titanium alloys at $183 \mathrm{~m} / \mathrm{min}$ cutting speed with internal through coolant. Based on the above investigation, they suggested that to the high speed drilling performance can be increased by employing a proper drilling parameters, spiral point drill geometry and fine grained WC-Co tool.

The aim of this research is to study the performance of HSD on Ti6Al4V with respect to cutting force, vibration, chip formation and surface integrity at various cutting conditions.

\section{Experimental Set Up}

Titanium alloy (Ti6Al4V) plate of $80 \mathrm{~mm} \times 150 \mathrm{~mm} \times 10.5 \mathrm{~mm}$ was prepared and attached to a Kistler dynamometer, type $9345 \mathrm{~A}$ for thrust force and torque measurement. A data acquisition system comprising a computer, NI-DAQ interface card, Kistler vibration sensors type 8776A50M6 and Dewetron software were used to record the vibration signals. HSD tests were carried out using a Mazak Variaxis 500-5X machining center. The drilling trials were confined to through holes and the cutting parameters were shown in Table 1. All the drills have a similar substrate composition of WC (92- $94 \%)$ and Cobalt $(6-8 \%)$. Samples of chips were collected and perpendicularly mounted in conductive bakelite resins, ground and etched before examined under the optical microscope. Subsurface deformation samples were examined and analyzed using the optical and scanning electron microscope (SEM). The surface roughness values of the drilled holes were measured using Mitutoyo surface roughness tester at four locations $\left(0^{\circ}, 90^{\circ}, 180^{\circ}, 270^{\circ}\right)$ for each hole. Five measurements were taken for each location to obtain the average surface roughness value. 
Table 1: Drilling test conditions.

\begin{tabular}{|l|l|}
\hline Tool & Tungsten carbide (WC-Co)-K10 \\
\hline Drill diameter & $6 \mathrm{~mm}$ \\
\hline Drill types & $\begin{array}{l}\text { Bevel ground, web thinning, } \\
\text { split point }\end{array}$ \\
\hline Helix angle & $25^{\circ}$ \\
\hline Point angle & $130^{\circ}$ \\
\hline Cutting speed & 50,60 and $70 \mathrm{~m} / \mathrm{min}$ \\
\hline Feed & 0.05 and $0.1 \mathrm{~mm} / \mathrm{rev}$ \\
\hline Drilling depth & $10.5 \mathrm{~mm}$ (through hole) \\
\hline Drilling method & Direct and peck \\
\hline Cutting fluid & Water soluble \\
\hline
\end{tabular}

\section{Results and Discussions}

\subsection{Results and Discussions}

Figures 1 and 2 show the effect of cutting speeds on the thrust force and torque in HSD of Ti6Al4V respectively. The average thrust force shows a decreasing trend as the cutting speed is increased from $50 \mathrm{~m} / \mathrm{min}$ to $70 \mathrm{~m} / \mathrm{min}$. The reduction in coefficient of friction on the tool face at high cutting speed contributed to low thrust force. In addition, low thrust force was also associated with a much smaller contact area on the rake face of cutting tool [21]. According to Ezugwu et al. [19], the reduction of tool-chip contact area when machining titanium alloys was due to thinner chip produced and the softening of the work material in the shear zone by the generated heat. Furthermore, cutting temperature becomes higher at higher cutting speed resulted in low extruding resistance on the chisel edge.

The torque values decreased in accordance with increases in cutting speed under all tested cutting conditions. From the figure, it can be seen that direct drilling method required higher torque when compared with peck drilling method. From the obtained results, drilling method exhibited significant effect on the thrust force and torque. At cutting speed of 70 $\mathrm{m} / \mathrm{min}$, direct drilling method indicates an increase of $4.7 \%$ and $13.6 \%$ of thrust force at feed $0.05 \mathrm{~mm} / \mathrm{rev}$ and $0.1 \mathrm{~mm} / \mathrm{rev}$ respectively as compared to the peck drilling method. Furthermore, the average values of the thrust force and torque increase with increase in drilling feed. Higher feed results in larger cross sectional area of the undeformed chip, greater chip deformation and consequently greater thrust force. It can be suggested that, in order to avoid the large thrust force and torque, low feed should be employed. When comparing with two different drilling methods, peck drilling method contributed to a lower thrust force and torque at all cutting conditions tested. The overall effect of cutting speed on the drilling torque is less than that of the feed. For direct drilling method, the highest torque of $2.1 \mathrm{Nm}$ and $3.08 \mathrm{Nm}$ were recorded at feed $0.05 \mathrm{~mm} / \mathrm{rev}$ and $0.1 \mathrm{~mm} / \mathrm{rev}$ respectively and at the lowest cutting speed of $50 \mathrm{~m} / \mathrm{min}$. At similar cutting speed and feeds, peck drilling method recorded the torque values of $2.05 \mathrm{Nm}$ and $2.99 \mathrm{Nm}$ respectively. This indicates that an increase of $2.4 \%$ and $3.0 \%$ were achieved at feed $0.05 \mathrm{~mm} / \mathrm{rev}$ and 0.1 $\mathrm{mm} / \mathrm{rev}$ respectively by direct drilling method. 


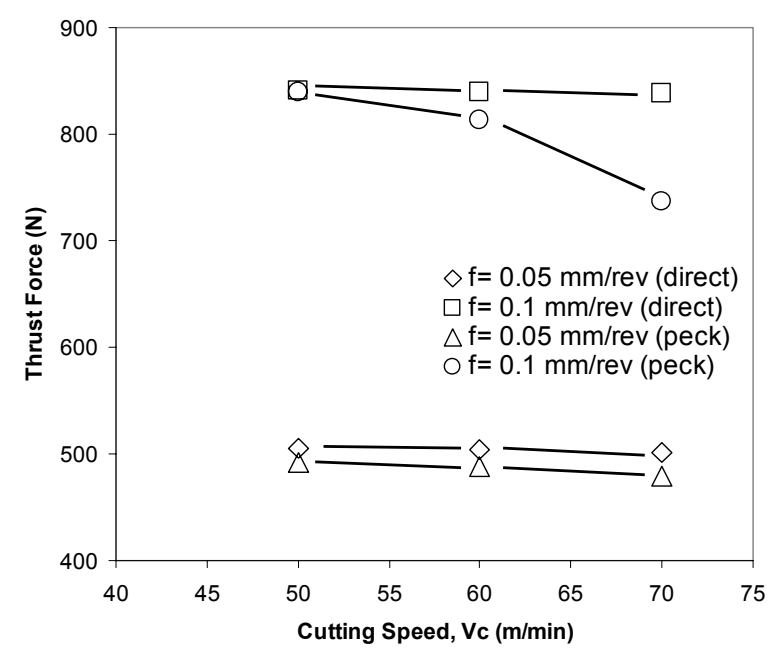

Figure 1: Thrust force versus thrust force using different type of drilling methods

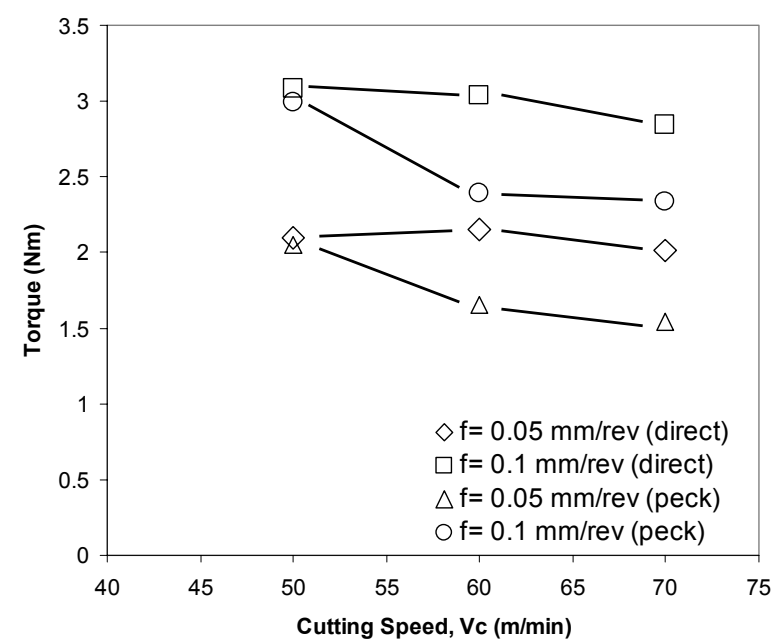

Figure 2: Torque versus cutting speed using different type of drilling methods

\subsection{Vibration}

Vibrations data were recorded using the data acquisition system for all cutting conditions tested. Analysis of the Fast Fourier Transformation (FFT) output was done with respect to peak frequency and the highest amplitude values. Tables 2 and 3 show a comparison of maximum acceleration amplitudes at three different frequency ranges for different drilling methods and conditions. It was observed from Figure 3(a) and Table 2 that the highest amplitude vibration peak of $0.0665 \mathrm{~g}$ in the frequency range of 1001 to 25000 $\mathrm{Hz}($ at $1406.25 \mathrm{~Hz}$ ) at cutting speed $50 \mathrm{~m} / \mathrm{min}$ and feed $0.05 \mathrm{~mm} / \mathrm{rev}$ for direct drilling method.

The next significant peaks of magnitudes $0.0228 \mathrm{~g}$ and $0.0337 \mathrm{~g}$ were observed in the frequency range of 50 to $500 \mathrm{~Hz}$ (at $361.33 \mathrm{~Hz}$ ) and 501 to $1000 \mathrm{~Hz}$ (at $712.89 \mathrm{~Hz}$ ) respectively. From Figure 3 (b) and Table 2, it was found that using peck drilling method results in reduction of high vibration amplitude. The three highest peaks of amplitude according to the frequency range observed at this condition were $0.0094 \mathrm{~g}, 0.0150 \mathrm{~g}$ and $0.0121 \mathrm{~g}$ in frequency ranges of 50 to $500 \mathrm{~Hz}$ (at $78.13 \mathrm{~Hz}$ ), 501 to $1000 \mathrm{~Hz}$ (at $800.78 \mathrm{~Hz}$ ) and 1001 to $2500 \mathrm{~Hz}(1025.39 \mathrm{~Hz})$ respectively. The reductions in amplitudes of these 
peaks compared to those of direct drilling method were $58.64 \%, 60.21 \%$ and $81.80 \%$ respectively.

Table 2: Peak acceleration and amplitude during direct and peck drilling method

\begin{tabular}{|c|c|c|c|c|c|}
\multicolumn{4}{c}{$(\mathrm{Vc}=50 \mathrm{~m} / \mathrm{min}$ and $\mathrm{f}=0.05 \mathrm{~mm} / \mathrm{rev})}$. \\
\hline \multirow{2}{*}{$\begin{array}{c}\text { Freq Range } \\
(\mathrm{Hz})\end{array}$} & \multicolumn{3}{|c|}{ Max Amplitude $(\mathrm{g})$} & \multicolumn{2}{|c|}{$\begin{array}{c}\text { Max Frequency } \\
(\mathrm{Hz})\end{array}$} \\
\cline { 2 - 6 } & Direct & Peck & $\%$ & Direct & Peck \\
\hline $50-500$ & 0.0228 & 0.0094 & 58.64 & 361.33 & 78.13 \\
\hline $501-1000$ & 0.0377 & 0.0150 & 60.21 & 712.89 & 800.78 \\
\hline $1001-2500$ & 0.0665 & 0.0121 & 81.80 & 1406.25 & 1025.39 \\
\hline
\end{tabular}

Table 3: Peak acceleration and amplitude during direct and peck drilling method $\mathrm{Vc}=70 \mathrm{~m} / \mathrm{min}$ and $\mathrm{f}=0.05 \mathrm{~mm} / \mathrm{rev}$ ).

\begin{tabular}{|c|c|c|c|c|c|}
\hline \multirow{2}{*}{$\begin{array}{c}\text { Freq Range } \\
(\mathrm{Hz})\end{array}$} & \multicolumn{3}{|c|}{ Max Amplitude $(\mathrm{g})$} & \multicolumn{2}{c|}{$\begin{array}{c}\text { Max Frequency } \\
(\mathrm{Hz})\end{array}$} \\
\cline { 2 - 6 } & Direct & Peck & $\%$ & Direct & Peck \\
\hline $50-500$ & 0.0494 & 0.0307 & 37.83 & 488.28 & 224.61 \\
\hline $501-1000$ & 0.0786 & 0.0413 & 47.46 & 615.23 & 820.31 \\
\hline $1001-2500$ & 0.1457 & 0.0513 & 64.78 & 1621.09 & 1357.42 \\
\hline
\end{tabular}

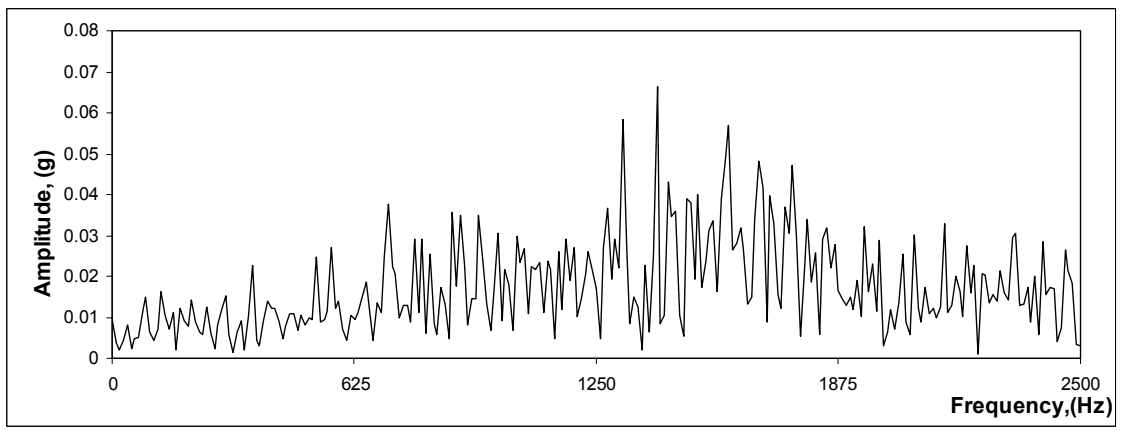

(a)

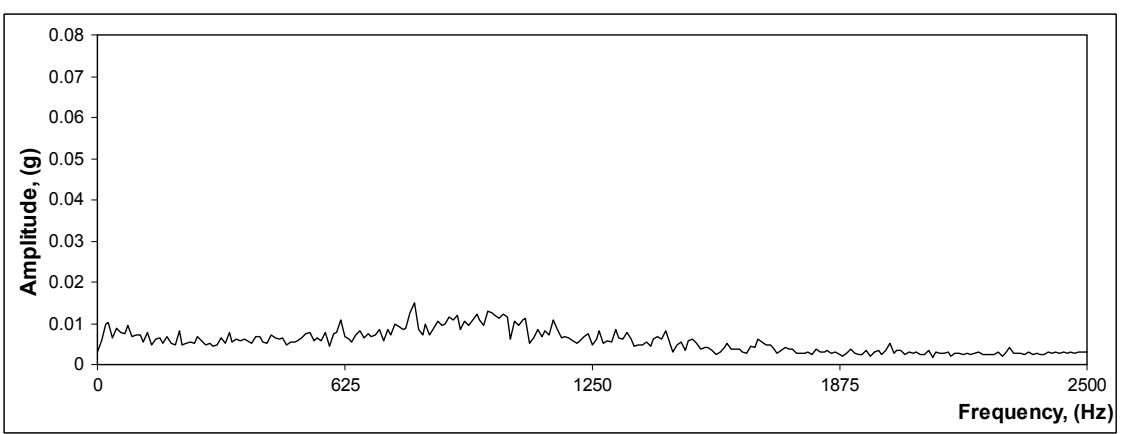

(b)

Figure 3: FFT output for $\mathrm{Vc}=50 \mathrm{~m} / \mathrm{min}$ and $\mathrm{f}=0.05 \mathrm{~mm} / \mathrm{rev}$; (a) direct and (b) peck drilling method. 


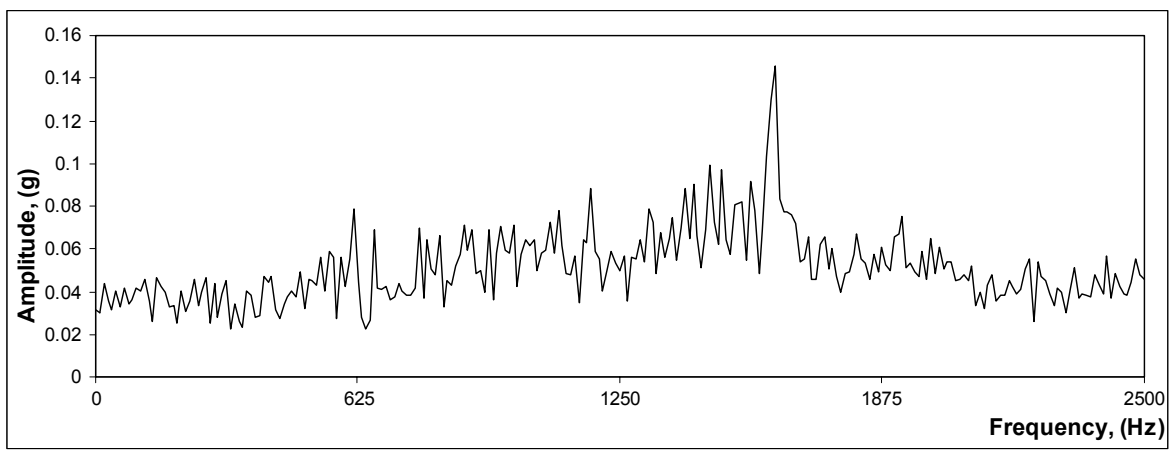

(a)

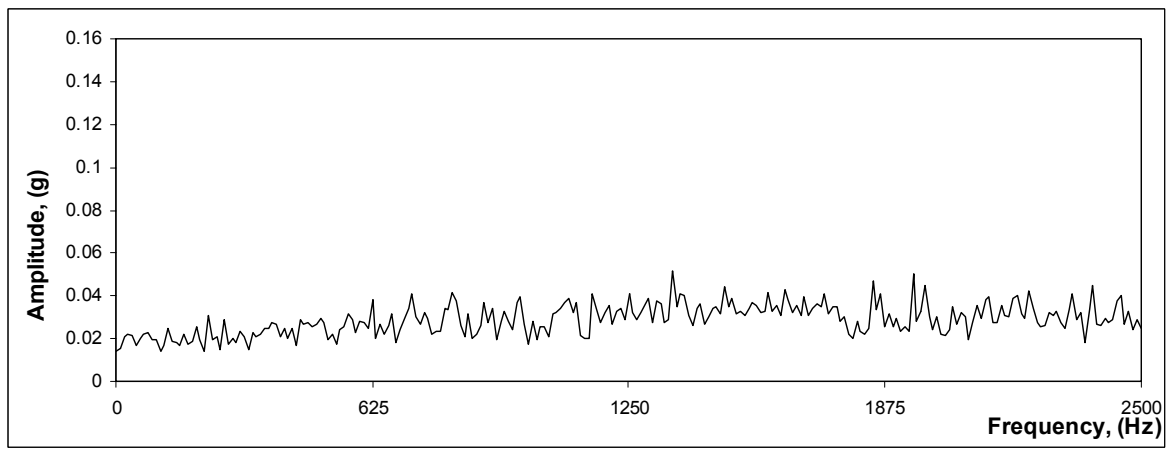

(b)

Figure 4: FFT output for $\mathrm{Vc}=70 \mathrm{~m} / \mathrm{min}$ and $\mathrm{f}=0.05 \mathrm{~mm} / \mathrm{rev}$; (a) direct and (b) peck drilling method.

It was observed from Figure 4(a) and Table 3 that during direct drilling method at cutting speed of $70 \mathrm{~m} / \mathrm{min}$ and feed $0.05 \mathrm{~mm} / \mathrm{rev}$, high amplitude vibrations were recorded with the highest peak of $0.1457 \mathrm{~g}$ in frequency range from 1001 to $2500 \mathrm{~Hz}$ (at 1621.09 $\mathrm{Hz}$ ). The next significant peaks of magnitudes $0.0494 \mathrm{~g}$ and $0.0786 \mathrm{~g}$ were recorded in the frequency range of 50 to $500 \mathrm{~Hz}$ (at $488.28 \mathrm{~Hz}$ ) and 501 to $1000 \mathrm{~Hz}$ (at $615.23 \mathrm{~Hz}$ ) respectively. It was also observed that the amplitude vibration for peck drilling method was significantly reduced as shown in Figure 4(b) and Table 3. The three highest peaks amplitude according to the frequency range observed at this condition are of amplitude values $0.0307 \mathrm{~g}$ in frequency ranges of 50 to $500 \mathrm{~Hz}$ (at $224.61 \mathrm{~Hz}$ ), $0.0413 \mathrm{~g}$ in frequency ranges of 501 to $1000 \mathrm{~Hz}$ (at $820.31 \mathrm{~Hz}$ ) and $0.0513 \mathrm{~g}$ in frequency ranges of 1001 to 2500 $\mathrm{Hz}(1357.42 \mathrm{~Hz})$ respectively. These three highest peak amplitude from different frequency range was lower compared to those by direct drilling method are $37.83 \%, 47.46 \%$ and $64.78 \%$ respectively.

\subsection{Chip Formation}

Figure 5 shows the photographs of the chips for direct and peck drilling method. In most cases, long folded wavy type chips and long curly type chips were produced at feed $0.05 \mathrm{~mm} / \mathrm{rev}$ and they were slightly longer than at feed of $0.1 \mathrm{~mm} / \mathrm{rev}$ for both drilling methods. In contrast, short folded wavy type chips were produced for feed of $0.1 \mathrm{~mm} / \mathrm{rev}$. In the case of drilling method, peck drilling produced shorter chip length when compared with direct drilling. When applying peck drilling method, there were no evidence of chip clogging in the drill flute. It indicated good chip evacuation from the hole and significantly reduced the chips adhesion on the cutting edges or drill flute which may clog the drilled hole.

Saw tooth chip formation has been observed at all cutting conditions as shown in 
Figures 6 (a) and (b). Most of the chips were discontinuous based from the significant formed of saw tooth. In general, the formation of saw tooth in machining titanium alloys is due to the instability of thermoplastic at primary shear zone. In this experiment, periodic chips formation was obvious probably due to the selected cutting speeds which fall within the high speed range. According to Barry et al. [20], chips can be categorized into two types, aperiodic and periodic. The transition from aperiodic to periodic chip formation occurred as the cutting speed increases.

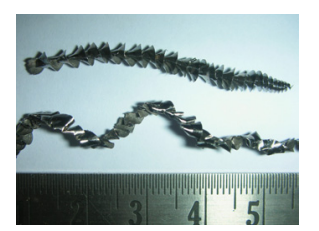

a) $\mathrm{Vc}=50 \mathrm{~m} / \mathrm{min}, \mathrm{f}=0.05$ $\mathrm{mm} / \mathrm{rev}$ (direct)

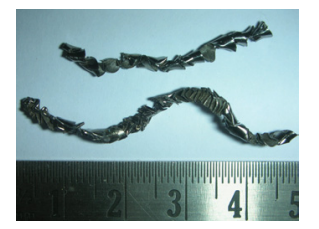

b) $\mathrm{Vc}=50 \mathrm{~m} / \mathrm{min}, \mathrm{f}=0.1$ $\mathrm{mm} / \mathrm{rev}$ (direct)

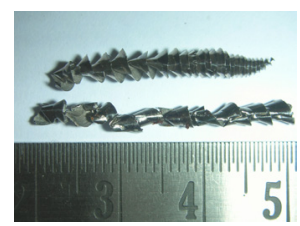

c) $\mathrm{Vc}=50 \mathrm{~m} / \mathrm{min}, \mathrm{f}=0.05$ $\mathrm{mm} / \mathrm{rev}$ (peck)

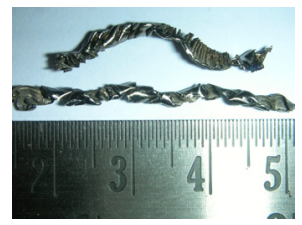

d) $\mathrm{Vc}=50 \mathrm{~m} / \mathrm{min}, \mathrm{f}=0.1$ $\mathrm{mm} / \mathrm{rev}$ (peck)

Figure 5: Comparison of chips shape.

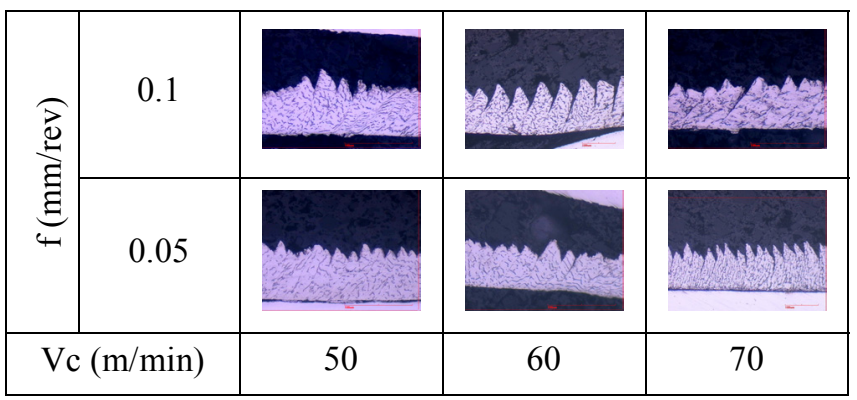

(a)

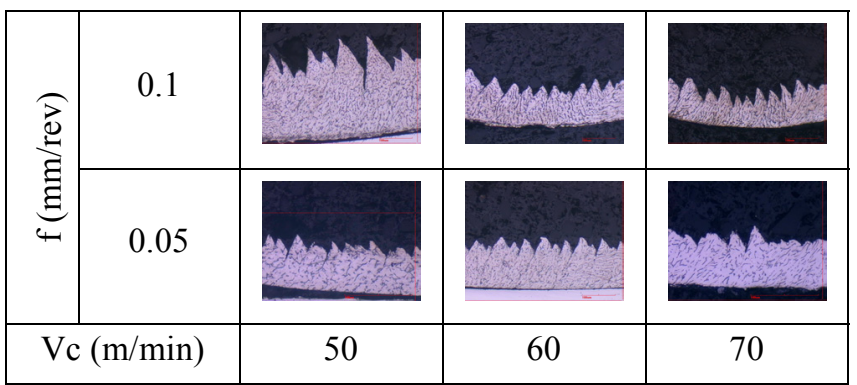

(b)

Figure 6: Saw tooth chip formation: a) direct drilling method, b) peck drilling method.

Figure 7 shows the average chip segmentation ratio as a function of cutting speed for various feeds and drilling methods. This ratio which is the average amplitude of the serrated teeth divided by thickness of the chip tends to decrease with increase in cutting speed from $50 \mathrm{~m} / \mathrm{min}$ to $70 \mathrm{~m} / \mathrm{min}$. Result also indicates that the feeds and drilling methods exhibited a significant influence on chip segmentation ratio. From the results obtained, the ratio for feed 
of $0.05 \mathrm{~mm} / \mathrm{rev}$ and direct drilling method are lower than that $0.1 \mathrm{~mm} / \mathrm{rev}$ and peck drilling method respectively.

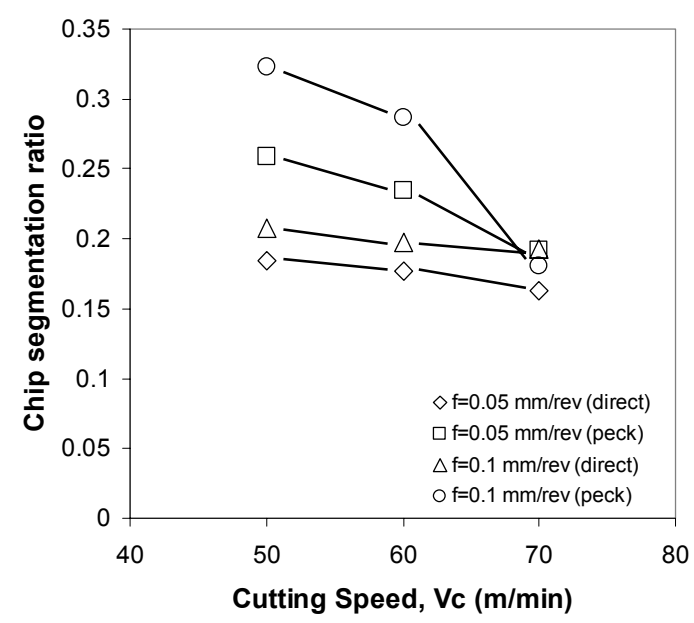

Figure 7: Chip segmentation ratio.

\subsection{Surface Roughness}

Figure 8 shows the value of surface roughness obtained on the first three holes when drilling Ti6Al4V. Results implied that cutting speed, feed and drilling methods affected the surface roughness value. The roughness value shows a decreasing trend with increase in cutting speeds from $50 \mathrm{~m} / \mathrm{min}$ to $70 \mathrm{~m} / \mathrm{min}$. It was suggested by Rahim and Sharif [16] that the absence of material side flow on the machined surface, small tool-workpiece contact length and the reduction the coefficient of friction contributed to better surface roughness. Furthermore, the feed plays a dominant factor in the drilling operation, following the drilling method. In general, the surface roughness measured for peck drilling method was far better than that measured for direct drilling method except for cutting speed $70 \mathrm{~m} / \mathrm{min}$ with feed $0.1 \mathrm{~mm} / \mathrm{rev}$.

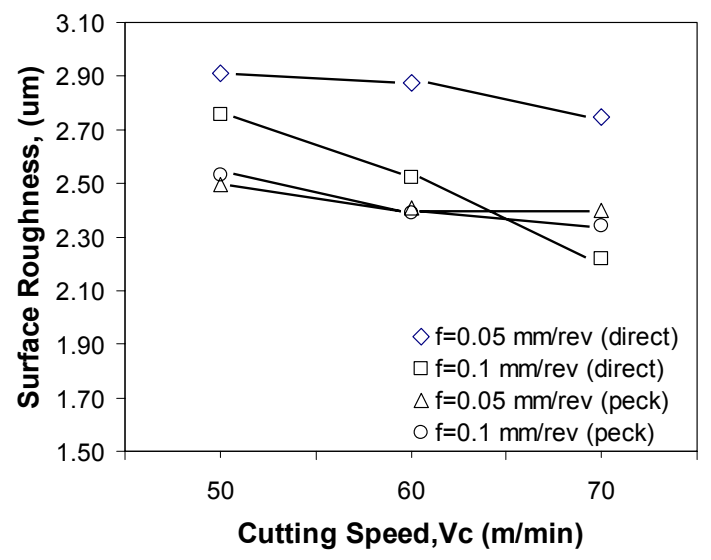

Figure 8: The surface roughness trends.

\subsection{Sub-surface Deformation}

The machined sub-surface structure was examined using the scanning electron microscope. Figure 9 shows a cross-section of the machined surface at cutting speed of 70 $\mathrm{m} / \mathrm{min}$. It was observed that metallurgical alterations occurred beneath the machined surface for all conditions tested. As shown in Figure 9, the microstructure grain tends to follow the direction of the drill rotation. It was probably due to the intense, localize and 
rapid thermal mechanical working during metallurgical transformation.

At high cutting speed, significant increase in cutting temperature could contribute to the softening of machined surface. According to previous researchers, the combination of high temperature and low cutting force at the tool-workpiece interface and coupled with high cutting speed can produce shear and compressive stress which lead to severe plastic deformation following the cutting direction [16].

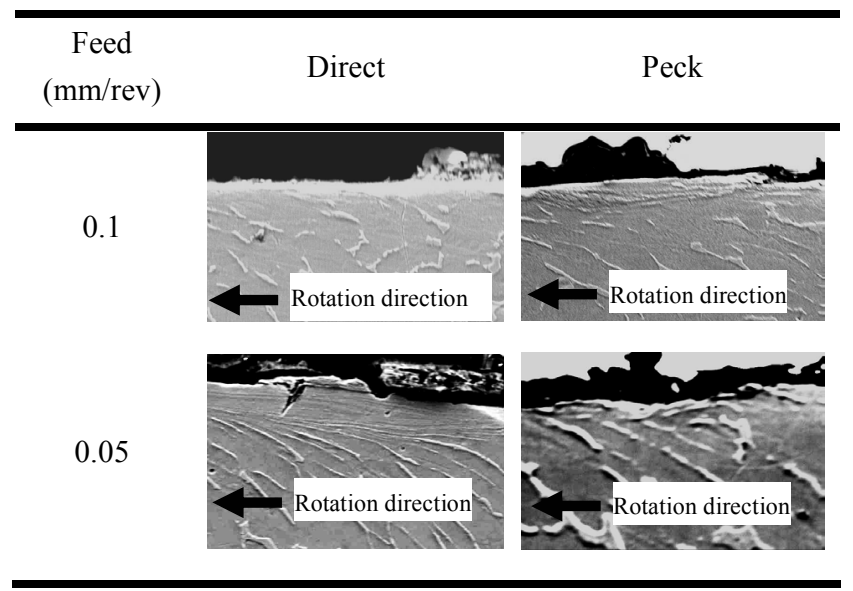

Figure 9: Sub-surface deformations at $\mathrm{Vc}=70 \mathrm{~m} / \mathrm{min}$.

\section{Conclusions}

The results obtained in this work suggest the following conclusions:

i. Cutting speed, feed and drilling methods (direct and peck) have significant effect on the thrust force and torque in HSD of Ti6Al4V.

ii. Approximately $80 \%$ reduction of acceleration amplitude of vibration has been recorded by peck drilling method as compared to direct drilling method which improved the HSD performance.

iii. $\quad$ Produced chips were folded wavy type chips and curly type chips under all tested cutting conditions. Periodic chips formation can be seen clearly in high cutting speed range.

iv. The average chip segmentation ratio tends to decrease with increase in cutting speed from $50 \mathrm{~m} / \mathrm{min}$ to $70 \mathrm{~m} / \mathrm{min}$.

v. The cutting speed, feed and drilling methods affected the surface roughness value.

vi. Severe plastic deformation was observed on the machined sub-surface at all cutting conditions investigated.

\section{Acknowledgement}

The authors would like to thank to the Ministry of Science, Technology and Innovation, Malaysia for financial support under the Science Fund Grant (Vote no. : S003) and Universiti Tun Hussein Onn Malaysia.

\section{References}

[1] Nieminen, I.; Paro, J.; Kauppinen, V.; 1996, High-Speed Milling of Advanced Materials, J. Mat. Proc. Tech., Vol. 56(1-4), pp.24-36.

[2] Rahman, M., Wang, Z.G., Wong, Y.S., An Overview of High Speed Machining of 
Titanium Alloys, Int. Conf. on Leading Edge Manuf., 2005, Nagoya, Japan.

[3] Dewes, R.C., Aspinwall, D.K., 1997, A Review of Ultra High Speed Milling of Hardened Steels, J. Mat. Proc. Tech., Vol. 69, pp. 1-17.

[4] Li, L., Chang, H., Wang, M., Zuo, D.W., He, L, 2004, Temperature Measurement in High Speed Milling, Key Eng. Mat., Vol. 259, pp. 804-808.

[5] Wang, Z. G., Rahman, M., Wong, Y.S., 2005, Tool Wear Characteristics of Binderless CBN Tools Used in High-Speed Milling of Titanium Alloys, Wear, Vol. 258, pp. 752-758.

[6] Wang, Z. G., Wong, Y. S., Rahman, M., 2005, High-speed Milling of Titanium Alloys using Binderless CBN Tools, Int. J. Mach. Tools and Manuf., Vol. 45, pp. 105-114.

[7] Rossman, E. F., 2003, Collected Thoughts on High Speed Machining of Titanium, SME Tech. Paper, MR03-347, pp. 1-8.

[8] Gente, A., Hoffmeister, H. W., 2001, Chip Formation in Machining Ti6Al4V at Extremely High Cutting Speeds, Ann. CIRP, Vol. 50, pp. 49-52.

[9] Kitagawa, T., Kubo, A., Maekawa, K., 1997, Temperature and Wear of Cutting Tools in High Speed Machining of Inconel 718 and Ti-6Al-6V-2Sn, Wear, Vol. 202, pp. 142-148.

[10] Kuljanic, E., Fioretti, M., Miani, F.,1998, Milling Titanium Compressor Blades with PCD Cutter, Ann. CIRP, Vol. 47, No. 1, pp. 61-64.

[11] Sakurai, K., Adachi, K., Kamekawa, T., Ogawa, K., Hanasaki, S., 1996, Intermittenly Decelerated Feed Drilling of Ti-6\%Al-4\%V Alloy, J. Light Metals, Vol. 46, No.3, pp. 138-143.

[12] Arai, M., Ogawa, M., 1997, Effects of High Pressure Coolant in Drilling of Titanium Alloy, J. Light Metals, Vol. 47 (3), pp. 139-144.

[13] Sharif, S., Venkatesh, V. C., Rahim, E. A., The Effects of Coatings on the Performance of Carbide Tools when Drilling Titanium Alloy Ti-6Al-4V, $8^{\text {th }}$ CIRP Int. Work. Modelling of Mach. Opt., 2005, Chemnitz, Germany, pp. 577-581.

[14] Cantero, J. L., Tardio, M. M., Canteli, J. A., Marcos, M., Miguelez, M. H., 2005, Dry Drilling of Alloy Ti-6Al-4V, Int. J. Mach. Tools \& Manuf., Vol. 45, pp. 1246-1255.

[15] Zeilmann, R. P., Weingaertner, W. L., 2006, Analysis of Temperature During Drilling of Ti6A14V with Minimal Quantity of Lubricant, J. Mat. Proc. Tech., Vol. 179, pp. 124-127.

[16] Rahim, E. A., Sharif, S., 2006, Investigation on Tool Life and Surface Integrity when Drilling Ti6Al4V and Ti5Al4V-Mo/Fe, Int. J. Japan Soc. Mech. Eng., Vol. 49, No. 2 (Series C), pp.340-345.

[17] Okamura, K., Sasahara, H., Segawa, T., Tsutsumi, M., 2006, Low-Frequency Vibration Drilling of Titanium Alloy, Int. J. Japan Soc. Mech. Eng., Vol. 49, No.1 (Series C), pp. 76-82.

[18] Rui Li, Hegde, P., Shih, A. J., 2006, High-Throughput Drilling of Titanium Alloys, Int. J. Mach. Tools \& Manuf., Vol. 47, No. 1, pp. 63-74.

[19] Ezugwu, E. O., Wang, Z. M., Machado, A. R., 2000, Wear of Carbides Tools When Machining Nickel and Titanium Based Alloys, Tri. Tran., Vol. 43, No.2, pp.263-268.

[20] Barry, J., Byrne, G., Lennon, D., 2001, Observation on Chip Formation and Acoustic Emission in Machining Ti-6Al-4V Alloy, Int. J. Mach. Tools \& Manuf., Vol.41, pp. 1055-1070.

[21] Rahim, E. A., Sharif, S., Kamarudin, K., 2006, Cutting Force and Chip Formation in Drilling Titanium Alloys, $8^{\text {th }}$ Int. Conf. on Progress of Mach. Tech., Nov. 2006, Matsue, Japan, pp. 37-40. 